\title{
CURRENT WESTERN MYTHS ABOUT RUSSIA
}

\author{
Sergey V. Biryukov \\ Centre for Russian Studies, East China Pedagogical University, Shanghai, China
}

\section{Oleg V. Omelichkin}

Kemerovo State University, Kemerovo, Russian Federation

\begin{abstract}
Introduction. The paper discusses the most common features of political myths which, with reference to Russia, are mainly built on superficial historical and cultural views on the political past of our country and a biased ideological assessment of contemporary political processes. In their research the authors use such methods as culturological, sociophilosophical and discourse analysis of public practices. The paper outlines the major topics highlighted in Western scientific literature and the media - Russia's underdevelopment, the authoritarian essence of the regime, its repressive nature, corruption, nationalism, violation of human rights and freedoms, aggressive foreign policy, etc. In the course of the analysis it is admitted that the Russian reality gives some grounds for such assumptions. At the same time, using some specific empirical data the authors put the critical judgments under corrective analysis and, consequently, refute many of them. Our opponents' main claim is Russia's inability or intentional unwillingness to become an organic part of Western civilization. Thereby, the critics refuse to recognise the right of the country to be conscious of its historical identity and to search for alternative routes of development. The research results consist in the conclusion that most Western myths manifest the denial of Russia as an autonomous power with its independent policy, and make an attempt to impose their own ideas and interests. However, a well-grounded and objective assessment of Russia is also to be heard from Western experts. The authors believe that the process of refusal from mutual accusations and stereotypes will be a long and difficult one, but it is crucial, too, if both sides are interested in establishing equitable partner relationships. To succeed in this, Russia has to overcome its internal challenges and contradictions and to secure ideological consensus and political consolidation of the society.

O. V. Omelichkin has studied the peculiarities of political myths and their reflection in political consciousness of modern Russia. S. V. Biryukov has paid special attention to the analysis of Western mythologems and the prospects of forming the foreign political image of the country.

Key words: myth, identity, culture, history, political processes, state, international relations.

Citation. Biryukov S.V., Omelichkin O.V. Current Western Myths about Russia. Vestnik Volgogradskogo gosudarstvennogo universiteta. Seriya 4, Istoriya. Regionovedenie. Mezhdunarodnye otnosheniya [Science Journal of Volgograd State University. History. Area Studies. International Relations], 2018, vol. 23, no. 6, pp. 185-196. (in Russian). DOI: https://doi.org/10.15688/jvolsu4.2018.6.15
\end{abstract}

Дата поступления статьи: 18.05.2018 Дата принятия статьи: 30.08 .2018

\section{СОВРЕМЕННЫЕ МИФЫ ЗАПАДА О РОССИИ}

\section{Сергей Владимирович Бирюков}

Восточно-Китайский педагогический университет, г. Шанхай, Китайская Народная Республика

\section{Олег Викторович Омеличкин}

Кемеровский государственный университет, г. Кемерово, Российская Федерация

Аннотация. Во введении рассмотрены основные характеристики политических мифов и показано, что в отношении нашей страны они базируются на поверхностных исторических и культурных взглядах на поли- 


\section{ПОЛИТИЧЕСКИЕ НАУКИ И РЕГИОНОВЕДЕНИЕ}

тическое прошлое России и тенденциозных идеологических и психологических оценках современных политических процессов. В качестве основных методов авторами используются культурологический, социально-философский и дискурсивный анализ публичных практик. Рассматриваются основные темы, поднимаемые в западной научной литературе и прессе: отсталость нашей страны, авторитарность режима, репрессивный характер государства, коррупция, национализм, нарушения прав и свобод личности, агрессивная внешняя политика и т. д. В ходе анализа отмечено, что сама российская действительность дает некоторые основания для подобных заключений. В то же время, используя конкретные данные, авторы корректируют критические суждения и опровергают многие из них. Главной претензией наших оппонентов является утверждение о неспособности или сознательном нежелании России стать органической частью западной цивилизации. Тем самым нашей стране отказывается в праве на историческую самобытность и поиски альтернативных путей развития. Результатом исследования является общий вывод о том, что в большинстве западных мифов проявляется неприятие России как самостоятельной державы и ее независимого политического курса и содержатся попытки навязать ей собственные представления и интересы. Встречаются и объективные суждения о нашей стране. Авторы считают, что процесс отказа от взаимных обвинений и стереотипов будет длительным и сложным, но он необходим для установления равноправных партнерских отношений. Для этого Россия должна преодолеть собственные трудности и добиться идейного консенсуса и консолидации всего общества.

О.В. Омеличкин рассмотрел особенности политических мифов и их отражение в политическом сознании современной России. С.В. Бирюков основное внимание уделил анализу западных мифологем и перспективам формирования внешнеполитического образа страны.

Ключевые слова: миф, идентичность, культура, история, политические процессы, государство, международные отношения.

Цитирование. Бирюков С. В., Омеличкин О. В. Современные мифы Запада о России // Вестник Волгоградского государственного университета. Серия 4, История. Регионоведение. Международные отношения. 2018. - T. 23, № 6. - C. 185-196. - DOI: https://doi.org/10.15688/jvolsu4.2018.6.15

Введение. Современное состояние отношений России и Запада характеризуется активной борьбой в политической, экономической, информационной и других сферах. Идейное противостояние неизбежно предполагает информационную войну - особую форму пропагандистской борьбы, в рамках которой регенерируются и активируются старые антироссийские мифы, имеющие своей итоговой целью разрушение символического капитала (П. Бурдье) российского общества и государства, их правомочности и самого права на существование в глазах собственного населения, дискредитацию страны с помощью средств «молекулярной агрессии» (А. Грамши) - целенаправленного информационного воздействия по разным каналам. Для этих целей активно используются политические мифы - формируемые в массовом сознании с помощью специальных технологий искаженные модели мира (вспомним «Технику политических мифов» Э. Кассирера). Политологический анализ данных мифов позволяет раскрыть их содержание и функциональные возможности.

Миф является первичной формой нормативной регуляции общественных отноше- ний, способом воздействия и контроля над поведением людей [4]. Он возникает на ранних стадиях человеческой истории и формирует социальную культуру, обеспечивающую самосохранение, самопознание и развитие общности. Миф опирается на устойчивые коллективные представления об окружающей действительности, основанные на вере и выражающиеся в стереотипах массового сознания. При этом он открыт и достаточно гибок, чтобы включать в свой состав новые знания и утверждения, не противоречащие его содержанию.

Таким образом, миф - это особая форма мировоззрения, для которой свойственны такие черты, как синкретичность (бессистемное соединение разнородных знаний), репродуктивность (восприятие определенной картины мира без ее анализа), некритичность и нерефлексивность, воспроизводимость и укорененность в массовом сознании, тесная связь с психологическими комплексами, стереотипами и фобиями. Он обладает высокой эмоциональной привлекательностью и социальной навязчивостью, устойчивостью и мобилизующей способностью. 
Мифы обладают структурностью и объяснительными возможностями, предлагают упорядоченную и целостную картину мира. Они отражают особое миропонимание, имеют собственную логику развития и формы доказательств. В силу этого миф универсален и самодостаточен.

По мнению Р. Барта, бороться с таким мифом можно путем искусственного конструирования другого мифа. Однако последующие образования еще больше отдаляются от действительности и стремятся подменять ее. Нередко они несут в себе деструктивное, разобщающее начало. Это проявляется в конфронтации и агрессивности по отношению к оппонентам. Именно этот путь создания вторичных мифов использует западная пропаганда в своих попытках «разоблачения» мифологем российской истории и современной практики.

Особенностью политических мифов является целенаправленный и сознательный процесс их создания, в котором реализуются политические интересы субъектов и их идеологические представления. Тем самым мифы выступают механизмом социальной интеграции и контроля над поведением граждан. На это указывает О.Ю. Малинова, отмечающая, что в «современной символической политике "миф" выступает в обоих качествах - в виде устоявшихся представлений, определяющих восприятие одних социальных групп, и в роли инструмента разрушения таких представлений (ради их замены собственными мифами) в руках других групп» [5, c. 19]. Таким образом, политические мифы выполняют одновременно объединяющую и экспансионистскую роль.

Методы и материалы. В исследовании мифа одним из наиболее известных является историко-культурный (антропологический) подход. Его сторонники (Дж. Фрэзер, С.С. Аверинцев и др.), разрабатывавшие понятие мифа применительно к древним и «традиционным» обществам, первыми отметили его социальную значимость и тем вызвали к нему особый интерес.

Плодотворен философско-культурологический анализ, сторонники которого (А.Ф. Лосев, М. Элиаде и др.) продолжают разработку представлений о мифе на современном материале. Они исходят из самоценности мифа и рассматривают его как явление культуры. Столь же перспективны символический подход (Э. Кассирер, П. Рикёр и др.) и исследования мифа в рамках семиологии (Р. Барт, Ю.М. Лотман и др.). Отметим позицию социальной философии, представители которой рассматривают социальную сущность мифа и определяют его как превращенную форму социального бытия, продуцирующую «иллюзорные конструкты сознания».

Наконец, в политической науке продуктивен дискурсивный метод, позволяющий исследовать политический миф как составную часть политического дискурса, как важный функциональный элемент, необходимый для воспроизводства публичного процесса в связи с феноменами идеологии, пропаганды и массового общественного сознания. Исследовать соотношение политических представлений, высказываний и политической реальности позволяет дискурсивный анализ, который заключается в изучении политического контента, воспроизводимого и транслируемого основными политическими акторами, которые действуют в рамках определенного контекста.

Авторы статьи стремятся к синтезу этих методов, делая основной упор на культурологический, социально-философский и дискурсивный анализ, рассматривая генезис антироссийских мифов и их соотношение с политическим процессом и актуальной политической реальностью.

Как отмечает специалисты (В.Ф. Шаповалов и др.), основы западного мифа о России окончательно сложились еще в 18301840-х гг. и с некоторыми модификациями остаются в силе и в наши дни. Подобная устойчивость объясняется не только инерционностью политического сознания, но и тем, что сама российская действительность дает основания для негативных умозаключений. При этом политические мифы о России обычно основаны на поверхностных исторических и культурных взглядах на политическое прошлое страны и тенденциозных идеологических и психологических оценках современных политических процессов.

Все политические мифы о России, создаваемые на Западе и у нас, условно можно разделить на несколько видов: 
1. Мифы о государстве, его устройстве и методах управления (деспотия или державность).

2. Мифы о российском обществе, его составе, культуре и формах жизнедеятельности (пассивность или героизм народа).

3. Мифы о положении личности, ее правах, свободах, безопасности и возможностях (авторитарный человек или созидатель).

Основные темы, затрагиваемые в западной научной литературе и прессе в настоящее время, - агрессивная внешняя политика, неэффективное государственное управление, коррупция, бюрократизм, нарушения прав и свобод личности, негативные свойства российского народа (пьянство, лень, воровство) и т. д. [6]. Многие проблемы существуют реально и не могут быть просто отвергнуты и объявлены легендами, выдумками, как это иногда встречается у исследователей.

Представления о России, ее истории, политике и культуре нашли отражение в обширной научной литературе в западных странах $[14 ; 15 ; 18 ; 21]$. Так, американские политологи Д. Фоглезонг и Г.М. Хан подробно рассмотрели некоторые мифы о России, распространенные в США. К ним относятся:

- миф о том, что события 1991 г. в России можно рассматривать как всенародную революцию во главе с либеральными демократами, которая свергла ненавистную народу коммунистическую систему и способствовала быстрому переходу страны к свободной рыночной экономике. Она ознаменовала победу российского гражданского общества над репрессивным государством;

- миф о том, что Россия неизбежно подчиняется логике некоего универсального закона развития, согласно которому у нее нет никакого выбора, кроме как, пусть и запоздало, копировать западный путь развития;

- миф о безнадежной невосприимчивости россиян к западным ценностям, обусловленной влиянием «ортодоксальной» церкви, бюрократизмом и коррупцией госаппарата, загадочной «славянской душой» и врожденными негативными качествами населения;

- миф о недостатке у населения «природных культурных» качеств и авторитарной политической культуре, при которых немыслима ни демократия, ни рыночная экономика;
- миф о Путине как о диктаторе. Говорят о жесткой централизации власти, подавлении оппозиции и инакомыслия;

- миф о непримиримой ненависти российских граждан к западному и особенно американскому образу жизни;

- миф о слабости России, которая больше не является серьезным игроком на международной арене, поэтому ею можно пренебречь при планировании американской внешней политики;

- миф о том, что США и Россия уже стали стратегическими партнерами и даже союзниками [16].

Подобные мифы создаются и воспроизводятся на страницах ведущих периодических изданий [17] и на различных сайтах в мировой сети [20]. По мнению многочисленных авторов, к основным составляющим образа современной России на Западе относятся: национализм и ксенофобия российского народа; антидемократичность политики и тоталитаризм государственного строя; нецивилизованность страны и неразвитость гражданского общества; экономическая и технологическая отсталость; агрессивность и экспансионизм на международной арене и т. п. Однако политические высказывания самих россиян носят значительно более взвешенный и объективный характер и уравновешиваются другими положительными оценками и выводами [10].

Полагаем, что в таком отношении Запада к России проявляется как общее представление о «цивилизационном» превосходстве Запада над обществом традиционного, точнее «общинного» типа, к которым относят Россию, так и влияние конкурентной борьбы с альтернативными формами исторического развития, создающей предпосылки для «русофобии». Но любое предвзятое и недостоверное мышление препятствует рациональному познанию России и протекающих в ней политических процессов.

Анализ. Современные претензии Запада к России обобщенно могут быть сведены к одной главной - Россия не хочет быть частью западной цивилизации. Причем неясно: она не стремится к этому сознательно или просто не может в силу своей «чужеродности»? При этом снимается вопрос, о какой 
именно западной цивилизации и идентичности идет речь, ибо Запад сам постепенно отказался от значимых элементов собственной идентичности: христианской религии и этики, рационалистического наследия Просвещения. В результате звучащее на Западе обвинение России в том, что она является «Ордой» в социокультурном смысле (то есть варварской и антиевропейской силой) несостоятельно, поскольку с точки зрения фактов истории Россия не «Орда», а именно преодоление «Орды» с опорой на собственный духовный «стержень» (православие) и отчасти за счет заимствования элементов западной культуры и цивилизации.

Многими отечественными и зарубежными авторами подчеркивается особая цивилизационная идентичность и самобытность России в мировом контексте. В их представлении мы выступаем как другая Европа. Но есть исследователи, которые говорят о чуждости российской политической культуры западной. При этом подчеркивается связь с восточным или азиатским миром или принадлежность к ним. Из этого делается вывод, что Запад никогда не сможет понять Россию. Однако существует и иная точка зрения. Так, В.Д. Соловей утверждает: «По своим практикам и стратегиям, по своим жизнеустроительным и политическим ценностям, по своему взгляду на внешний мир мы - нормальный европейский народ с нормальными европейскими потребностями» [11, с. 116]. Наконец, высказывается мнение, в частности В. Сурковым, что Россия - сдвоенная и двойственная цивилизация, одновременно европейская и азиатская и оттого не являющаяся ими вполне. Мы западно-восточная страна-полукровка, обладающая гибридной ментальностью и обреченная на геополитическое одиночество [13]. Каждая из данных версий имеет свое реальное и мифологическое обоснование.

Каковы же наиболее распространенные мифы о России, существующие и поддерживающиеся на современном Западе?

1. Миф о российском традиционализме как об источнике российского антиевропеизма и вражды к Западу, равно как о причине неприятия Россией ценностей толерантности и плюрализма.
В действительности в современной России нет полноценного консервативного и тем более традиционалистского консенсуса. Российское общество на сегодняшний день не готово к восприятию всего комплекса традиционных ценностей. Среди причин этого явления - неоднозначные последствия трансформационного процесса 1990-х гг., утвердившего в России, по признанию А.С. Ахиезера, своеобразную психологию «нелиберального индивидуализма», проявлением которой стало погружение индивида в частную жизнь при общей лояльности государству, но без желания раствориться в какой-либо новой коллективистской общности либо идентичности. Россияне стремятся поддерживать своеобразный неформальный «пакт о ненападении» с собственным государством, и в случае усиления этатического давления будут скорее отстаивать свои индивидуальные права, нежели отрефлектированные консервативные ценности. В то же время отсутствие устоявшегося ценностного «ядра» в сознании россиян не позволяет говорить об их полном ценностном релятивизме. С известными оговорками можно утверждать, что подобное «ядро» медленно и проблематично, но все же формируется.

Так, согласно опросу Левада-Центра, в марте 2017 г. только $10 \%$ россиян считали, что интересы государства должны ставиться выше, чем права отдельного человека. Еще $24 \%$ отвечали, что ради интересов государства в отдельных случаях можно согласиться с ущемлением прав отдельных граждан. При этом 47 \% утверждали, что люди имеют право бороться за свои права, даже если это идет вразрез с интересами государства, а $13 \%$ считали, что права отдельного человека должны ставиться выше, чем интересы государства [2]. Это свидетельствует о том, что либеральные ценности получили определенное распространение в нашем обществе. Однако важно не допускать в отношении граждан к государству крайних позиций.

2. Миф об извечном авторитарном комплексе россиян.

Увязывание западными СМИ обнаруженного «авторитарного комплекса» (как своего рода «вечного возвращения» России к своим историческим «истокам») происходит в связи с «политикой Путина». На взгляд авто- 


\section{ПОЛИТИЧЕСКИЕ НАУКИ И РЕГИОНОВЕДЕНИЕ}

ров, в этом случае скорее можно говорить о некоторой инверсии, которая предполагает неизбежность консервативно-государственнического ответа (и запроса социума на него) на периодически повторяющийся кризис или крушение определенной исторической формы российской государственности. В то же время высокий уровень поддержки президента России связан не с массовым запросом на «советскую реставрацию», а прежде всего со стремлением к формированию справедливого порядка на основе права, так и не сложившегося в результате реформ 1990-х гг. и трансформаций системы в 2000-е годы. Поэтому идея о существовании в современной России некоего «реакционного консенсуса», связанного с намерением российского общества консолидированно двигаться к тем или иным формам политической архаики, является мифологической и пропагандистской конструкцией.

При этом определенная централизация власти и системы управления была необходима для поддержания внутреннего единства и постоянной мобилизации общества, решающего сложные задачи в условиях большой дифференциации природных и социально-экономических факторов и внешних угроз.

3. Миф о торжествующем российском неосталинизме.

И. Сталин, несмотря на высокие рейтинги, пока не является фигурой консенсуса в современной России. Хотя в этой связи обычно ссылаются на итоги социологических опросов. Так, по данным Левада-Центра, в апреле 2017 г. на первое место среди самых выдающихся людей всех времен и народов респонденты поставили И. Сталина (38 \%). В 1989 г. таковых было 12 \%. Показательно, что только $39 \%$ оценивают сталинские репрессии как политическое преступление, которому не может быть оправдания (в октябре 2012 г. - $51 \%$ ), а 25 \% полагают, что в них была политическая необходимость и они исторически оправданы. При этом 36 \% либо ничего не знают об этих репрессиях, либо затрудняются с ответом или отказываются отвечать. Все это позволяет говорить о наметившейся двойственности восприятия фигуры Сталина и политики сталинизма в российском обществе. Причем количество его постоянных сторонников почти не увеличилось. По- этому сейчас необходимо, особенно для молодых людей, объективно показать реальные масштабы и последствия сталинских репрессий и дать взвешенную политическую и моральную оценку их руководителям и исполнителям [12].

Миф о возрождающемся российском «неосталинизме», с которым некоторые западные эксперты увязывают суть современной политической стратегии российских властей, имеет особое значение для определения отношения немалой части западного сообщества к России. На наш взгляд, речь сегодня может идти о селективном использовании отдельных идеологем из сталинистского дискурса в рамках «синкретической» по своему характеру официальной идеологии российской власти.

Однако, как показывает анализ реальных политических практик, не только к сталинизму, но и к какому-либо иному варианту мобилизационной стратегии (проекту) российская правящая элита не стремится. Говорить о «сталинистском ренессансе» в массовом сознании россиян также было бы очевидным преувеличением, поскольку все подобные проявления никак не связаны и не предполагают ревизии социально-экономического курса и подкрепляющих его политических мер, сложившихся в 90-е годы. Поэтому элементы идеологической «ресталинизации» могут рассматриваться не иначе как инструмент управления массовыми социальными ожиданиями и настроениями в непростой общественно-политической ситуации.

4. Миф о президенте В. Путине.

Главным «героем» западных мифов о России выступает президент В.В. Путин. Обычно имеет место демонизация образа политического лидера страны, который наделяется исключительно отрицательными чертами (агрессивность, жестокость, цинизм и т. п.). Подчеркивается его былая принадлежность к КГБ. Одновременно разрабатывается и смягченный вариант мифа о Путине как последовательном неоевразийце.

В ряду «инспирированных раздражителей» западного общественного мнения миф о Путине как о последовательном неоевразийце и неославянофиле, проводнике в жизнь специфически-антизападной идеологической 
платформы, предполагающей едва ли не изначальную конфронтацию с «цивилизованным сообществом» и «онтологически» враждебной ценностям и устремлениям Запада, занимает особое место. С помощью этого мифа В. Путина нередко преподносят общественному мнению как вдохновленного консервативной идеологией «неосоветского» реставратора, обращенного в «дореволюционные архаические времена». При этом в действительности, как нам представляется, речь может идти лишь о попытке расширить пространство политического и идеологического маневра и сформировать дополнительные факторы консолидации в условиях «ценностной неопределенности», переживаемой по сей день российским обществом. Однако западные исследователи не готовы либо не хотят воспринимать сложную и противоречивую динамику российского политико-идеологического дискурca, который складывается на месте масштабного ценностного вакуума, возникшего в 90-е годы.

В действительности же, как показывает анализ его деятельности, В. Путин - политик европейской формации и ценностной ориентации, действующий в рамках специфической ситуации, связанной с нежеланием российской элиты «интегрироваться в Европу» ценой упразднения (умаления) России как геополитической целостности и цивилизационного проекта. В этой ситуации президент России пытается найти идеологические основания для геополитического позиционирования страны, связанного с новыми вызовами и угрозами.

Весьма показательно, что большинство россиян в настоящее время поддерживают политический курс руководства страны. Так, в апреле 2018 г. 60 \% опрошенных сказали, что дела в стране идут сегодня в целом в правильном направлении, а $26 \%$ считают, что страна движется по неверному пути, 14 \% затруднились ответить. При этом $82 \%$ одобряли деятельность В. Путина на посту президента России, не одобряли - 17 \% [7]. Данные опроса свидетельствуют, что абсолютной поддержкой населения пользуется только президент страны. В обществе, действительно, существует запрос на «героя-спасителя», отличающегося честностью, справедливостью, сильной волей. Деятельность высших органов законодательной и исполнительной власти вызывает критические замечания и не получила полного одобрения у населения.

5. Миф о русском национализме.

На наш взгляд, в современных условиях, особенно после событий весны 2014 г. на Украине и Донбассе, русский этнический национализм как значительная консолидированная сила переживает состояние масштабного раскола, депривации и маргинализации. Говорить о «подъеме» и перспективах национализма как организованного массового общественного движения и о его системном противостоянии государству сегодня не приходится. В этой связи попытки демонизировать российский национализм, преувеличивая его политические возможности и подавая его в качестве «масштабной угрозы западной цивилизации», выглядят откровенно контрпродуктивными. Игнорирование западными исследователями того факта, что русский национализм как явление не может существовать в виде сколько-нибудь значимой социальной силы вне державнического лагеря и его идеологии, произвольное смешение русского национализма с «великорусским шовинизмом» выдает непрофессионализм либо очевидную ангажированность западных исследователей этого вопpoca. Стереотипное и мифологическое мышление последних в итоге приводит к неспособности реконструировать логику дискурса и политического процесса в современной России.

Подобная ангажированность критиков «поднимающегося русского национализма» тем более удивительна на фоне того факта, что на постсоветском пространстве (исключая Россию) именно национализм в различных его формах переживает состояние подъема, выступая очевидной реакцией на процесс создания бывшими советскими народами своих «титульных» национальных государств и наблюдаемые сегодня сложности их развития.

Показателен уровень толерантности в российском обществе. По данным ЛевадаЦентра, к представителям другой религии очень хорошо относятся $4 \%$ граждан, доброжелательно - $19 \%$, без особых эмоций $-58 \%$, настороженно - $14 \%$, очень плохо - $3 \%$. К людям другой национальности очень хорошо относятся $4 \%$, доброжелательно - $19 \%$, без особых эмоций $-57 \%$, настороженно $-15 \%$, очень 
плохо - 2 \%. К мигрантам, приезжающим в Россию из других стран, - соответственно $3 \%$, $13 \%, 54 \%, 21 \%$ и $6 \%$. В целом в обществе преобладает нейтральное отношение к данным проблемам, что, в принципе, в нынешней ситуации вполне приемлемо [3].

6. Миф о российских либералах как о прогрессивной силе, которой не дали провести реформы.

На противоположном идейно-политическом «полюсе» находится миф о российских либералах как о противниках действующего «репрессивного» режима и борцах за демократию. В действительности ключевые фигуры из числа российских либералов реально интегрированы в существующую властную систему либо стремятся в нее вернуться на привилегированном положении, инспирируя некоторое подобие бунта среднего и «креативного» класса с целью усиления своих статусных позиций и достижения политико-идеологической монополии, но не с целью качественного совершенствования «системы» в интеpecax большинства. Отказ от глубокой рефлексии по поводу результатов преобразований 90-х гг. и опасение реакции со стороны «консервативного большинства» - существенные сдерживающие для современных российских либералов факторы. Однако дефекты российской экономики, социальной структуры и системы управления во многом являются следствием специфически проведенных тогда реформ, породивших особые формы взаимоотношений власти и бизнеса в России.

Очевидно, что имевшийся либеральный сценарий в России предполагал «модернизацию элиты», но не «модернизацию страны», что объективно не удается скрыть с помощью популистских методов и лозунгов. В результате, не отрицая саму идею реформ, россияне остаются достаточно критичными к ее либеральной интерпретации, принципиально не доверяя многим из числа «носителей» и проводников либеральной идеи. Положительно относясь ко многим либеральным ценностям, они не слишком высоко оценивают способность последних к созданию эффективных экономических и правовых институтов, работающих на цели общего блага.

7. Миф о наступающем российском «империализме», набирающем силу и угро- жающем стабильности существующего миропорядка.

Многие зарубежные и российские критики выводят «историческую приверженность» России империалистическим стратегиям из пресловутого российского мессианизма, шовинизма и тяги к экспансии, которые будто бы угрожают человечеству. На самом же деле с позиции одного ресурсного анализа можно с известной твердостью утверждать, что на сегодняшний день у России нет последовательной имперской стратегии и ресурсов для восстановления империи. Действующая российская элита стремится интегрироваться в Запад, вопрос лишь в том, в каком именно статусе (этот статус является предметом спора). Российская элита ментально не готова к мобилизации и сколько-нибудь значительному самоограничению ради общих целей государства и общества, что лишает имперский проект надежных оснований. В отношении российского общества мобилизационная стратегия также не реализуется, а решительные шаги и заявления российской стороны скорее реакция на «неконвенциальные» действия Запада, не вписывающиеся в логику «статусного торга».

В контексте генерируемого и поддерживаемого немалой частью западных массмедиа «империалистического» мифа едва ли не любая интеграционная активность России в рамках СНГ воспринимается как проявление все того же империалистического комплекca. В то же время давление самого Запада на Россию и продолжающаяся экспансия в сферы ее традиционного влияния никоим образом не увязывается западными оппонентами с собственными империалистическими намерениями.

Говоря о влиянии, которое Россия сегодня имеет в международных делах, $86 \%$ респондентов считают его очень или довольно большим, а на вопрос, сможет ли Россия в ближайшие 15-20 лет стать великой державой, $31 \%$ ответили утвердительно, $10 \%$ - отрицательно, а 57 \% полагают, что она уже является одной из великих держав [9]. Важно отметить, что, по мнению граждан, приоритетами во внешней политике руководства России должны быть: обеспечение мирного и безопасного существования страны (59 \%), восста- 
новление авторитета России как одной из самых влиятельных стран в мире, без голоса которой не решается ни один из важнейших вопросов (49 \%), поддержание дружественных отношений с наиболее развитыми странами $(27 \%)[8]$.

Результаты. Анализ приведенных примеров показывает, что у Запада со всей очевидностью проявляется дефицит рефлексии в отношении России, для устранения которого необходим отказ от шаблонного и конформистского критицизма и адекватность в восприятии сложившихся реалий. Как представляется, процесс отказа от обоюдных мифов и стереотипов будет достаточно тяжелым и может быть связан с окончанием современного противостояния Запада и России. К сожалению, взаимные подозрения и претензии не исчезли, а периодические сближения интересов не приводят к установлению прочных партнерских отношений.

Как отмечает Г. Вайнштейн, в сложившемся на Западе образе России (как, впрочем, и любой другой страны) преобладают компоненты иррационального характера. Объективные характеристики страны не столько отражаются, сколько преломляются и искажаются в соответствии с интересами и стереотипами наших оппонентов. И это объясняется отнюдь не плохой информированностью или догматизмом западных политических кругов. «Налицо скорее совершенно осознанное неприятие всего связанного с Россией, воспринимаемой как страна, не только чуждая Западу в культурном и ценностном смысле, но и проводящая политику, ущемляющую западные интересы» [1, с. 16].

Живучесть многих политических мифов о России можно объяснить особенностями непростого исторического и политического развития нашей страны, сложностью ее современного состояния, стремлением к самоопределению и росту, а также давно сформировавшимися на Западе стереотипами, заинтересованностью западных элит в поддержании негативного отношения к нашей стране. Эти мифы отражают существующие в западном обществе фобии и страхи, имеют предвзятый и агрессивный характер и являются основаниями для недружественных политических действий в отношении России. Тем самым они препятствует установлению устойчивых и предсказуемых отношений и переходу к полноценному политическому диалогу.

Можно предположить, что рассматриваемые нами мифы и стереотипы в значительной степени характеризуют черты самого западного политического сознания, а не только российскую действительность. Данное суждение разделяет М. Малиа, который отмечает, что существование ряда расхожих клише о России объясняется скорее проблемами самого Запада. Общественное мнение этих стран традиционно «демонизировало или, напротив, идеализировало Россию» не столько из-за ее реальной роли в европейской политике, сколько из-за собственных страхов и фрустраций или надежд и стремлений, порождаемых в европейском обществе собственными внутренними проблемами $[19$, p. 6]. Причем данные установки и стереотипы рассчитаны не только на западного обывателя, но и косвенным образом сориентированы на российские власти с целью оказания на них определенного давления. Они являются важным инструментом формирования западной политики на постсоветском пространстве.

По глубокому убеждению авторов, преодолеть состояние современного кризиса и отстоять свои позиции в «культурных войнах» со странами Запада Россия сможет лишь достигнув определенного идейно-мировоззренческого консенсуса и консолидации. Что же мы имеем сегодня в качестве исходных предпосылок для позитивной реконструкции внешнеполитического образа нашей страны?

1. В России нет непримиримого противоречия между индивидуализмом и коллективизмом, они сравнительно гармонично дополняют друг друга в повседневности, хотя данное положение не осмыслено в полной мере в массовом сознании и не отражено должным образом в официальной идеологии.

2. В сознании российского общества не существует непримиримого антагонизма между западными и собственно российскими ценностями, допускается их взаимодействие, хотя вопрос о взаимоотношениях между ними не отрефлексирован до конца.

3. В массовом сознании российского общества не преобладают «в чистом виде» ни социалистические, ни либеральные, ни иные 


\section{ПОЛИТИЧЕСКИЕ НАУКИ И РЕГИОНОВЕДЕНИЕ}

ценности, но при этом комбинируются элементы разных идеологических комплексов, вследствие чего их соединение не всегда выглядит противоестественным и социально контрпродуктивным.

4. Российское политическое сознание отражает в себе специфику геополитического положения России и связанных с ним международных проблем (безопасность и пр.), но в то же время в большей степени озабочено проблемами внутреннего развития страны.

5. Российское массовое сознание предпочитает мирные и эволюционные варианты развития страны мобилизационным и конфронтационным и не содержит в себе устойчивых и очевидных принципов «тоталитарного синдрома» и «синдрома осажденной крепости».

6. При наличии социального напряжения и межгрупповых противоречий российское политическое сознание не является «классово-антагонистическим», поэтому не создает в обществе существенных предпосылок для масштабного противостояния групп.

7. Российские политическая элита и государство стремятся учитывать существующие в обществе настроения и запросы, пытаясь соединять их с интересами сохранения политического порядка и собственных статусных позиций.

Среди наиболее общих особенностей социокультурной динамики в современной России в качестве элементов базовой гипотезы выделим следующие:

1. В рамках социокультурного пространства России сосуществуют несколько ценностных «протоядер», которые пока не приобрели характеристик устойчивых и отрефлектированных ценностно-мировоззренческих комплексов.

2. Соотношение «протоядер» с основными существующими группами интересов условно, границы социальных и мировоззренческих страт часто не совпадают.

3. Комплиментарность (совместимость) сложившихся ценностно-мировоззренческих «протоядер» также условна, в то время как их долговременное инерционное сосуществование позволяет пока избежать глубокого ценностного раскола в российском обществе.

4. «Протоядра» пока не могут быть трансформированы в полноценные разновидности общественной идеологии.
5. События, начавшиеся в 2014 г. и связанные с активизацией как официальной, так и оппозиционной пропаганды в России, равно как и с общим оживлением политической жизни, могут в обозримое время привести к ускорению процесса констелляции ценностно-мировоззренческих «протоядер» и к их трансформации в общественные идеологии (государственно-патриотическую, либеральную, неосоциалистическую).

Можно предположить, что по мере развития российского гражданского общества и государства, укрепления его экономического и политического потенциала на первый план выйдут не узкоэтнические или групповые, а державно-патриотические гражданские ценности и нормы. Они будут способствовать сохранению российской идентичности и консолидации многонационального российского народа, укреплению государственной власти и всей системы политического управления. На этой основе должны усилиться международные позиции страны и укрепятся ее связи с мировым сообществом.

\section{СПИСОК ЛИТЕРАТУРЫ}

1. Вайнштейн, Г. Россия глазами Запада: стереотипы восприятия и реальности интерпретации / Г. Вайнштейн // Неприкосновенный запас. - 2007. № 1. - C. 13-23.

2. Интересы государства и права человека // Левада-Центр. - Пресс-вып. от 03.04.2017. - Электрон. текстовые дан. - Режим доступа: https:// www.levada.ru/2017/04/03/interesy-gosudarstva-iprava-cheloveka/ (дата обращения: 17.04.2018). Загл. с экрана.

3. Ксенофобия в 2017 году // Левада-Центр. Пресс-вып. от 23.08.2017. - Электрон. текстовые дан. - Режим доступа: https://www.levada.ru/2017/ 08/23/16486/ (дата обращения: 17.04.2018). - Загл. с экрана.

4. Лукашева, Е. А. Современная мифология и реалии политической и социальной жизни / Е. А. Лукашева // Труды Института государства и права Российской академии наук. - 2012. - № 3. - С. 5-35.

5. Малинова, О. Ю. Миф как категория символической политики: анализ теоретических развилок / О. Ю. Малинова // Политические исследования. -2015 . - № 4. - С. 12-21.

6. Мединский, В. Р. О русском пьянстве, лени и жестокости / В. Р. Мединский. - М. : ОЛМА Медиа Групп, 2009. - 560 с. 
7. Одобрение институтов власти // ЛевадаЦентр. - Пресс-вып. от 25.04.2018. - Электрон. текстовые дан. - Режим доступа: https://www.levada.ru/ 2018/04/25/odobrenie-institutov-vlasti-2/ (дата обращения: 11.05.2018). - Загл. с экрана.

8. Приоритеты во внешней политике // Левада-Центр. - Пресс-вып. от 17.08.2017. - Электрон. текстовые дан. - Режим доступа: https://www. levada.ru/2017/08/17/prioritety-vo-vneshnej-politike/ (дата обращения: 17.04.2018). - Загл. с экрана.

9. Россия - великая держава // ВЦИОМ. Пресс-вып. № 3327 от 15.03.2017. - Электрон. текстовые дан. - Режим доступа: https:/wciom.ru/ index.php?id=236\&uid=116111 (дата обращения: 17.04.2018). - Загл. с экрана.

10. Рюмин, А. М. Современные стереотипы о России в массовом сознании жителей стран Запада : автореф. дис. ... канд. социол. наук / Рюмин Алексей Михайлович. - Н. Новгород, 2012. - 21 с.

11. Соловей, В. Д. Мифы о России vs реальность / В. Д. Соловей // Сравнительная политика. 2012. - № 1. - С. 110-116.

12. Сталинские репрессии // Левада-Центр. Пресс-вып. от 23.05.2017. - Электрон. текстовые дан. Режим доступа: https:/www.levada.ru/2017/05/23/ stalinskie-repressii/ (дата обращения: 17.04.2018). Загл. с экрана.

13. Сурков, В. Одиночество полукровки (14+)/ В. Сурков // Россия в глобальной политике. - 2018. № 2. - C. 124-129.

14. David-Fox, M. Crossing borders : modernity, ideology, and culture in Russia and the Soviet Union / M. David-Fox. - Pittsburgh : University of Pittsburgh Press, 2015. - 286 p.

15. Dimkann, P. Russian messianism: Third Rome, revolution, communism and after / P. Dimkann. - N. Y. ; L. : Routledge, 2000. -235 p.

16. Foglesong, D. Ten myths about Russia: Understanding and dealing with Russia's complexity and ambiguity / D. Foglesong, G. M. Hahn // Problems of Post-Communism. - 2002. - Vol. 49, № 6. - P. 3-15.

17. Gessen, M. Five myths about Russia / M. Gessen // The Washington Post. - 2016. - Oct. 7. Electronic text data. - Mode of access: https:// www.washingtonpost.com/opinions/five-mythsabout-russia/2016/10/07/1df1671a-8bd3-11e6-bf8a$3 \mathrm{~d} 26847$ eeed4_story.html?utm_term $=.3 \mathrm{~b} 4 \mathrm{~b} 69 \mathrm{f} 4 \mathrm{ee} 41$ (date of access: 17.04.2018). - Title from screen.

18. Gill, G. Symbols and legitimacy in Soviet politics: The life and death of the USSR / G. Gill. Cambridge : Cambridge University press, 2011. - 364 p.

19. Malia, M. Russia under Western Eyes: From the Bronze Horseman to the Lenin Mausoleum / M. Malia. Cambridge; L. : Harvard University Press, 1999. - 514 p.

20. Shakarian, P. Debunking 8 myths about Russia and the former Soviet space (Oct 3, 2014) / P. Shakarian
// Russia Direct. - Electronic text data. - Mode of access: http://www.russia-direct.org/analysis/ debunking-8-myths-about-russia-and-former-sovietspace (date of access: 17.04.2018). - Title from screen.

21. Tismaneanu, V. Fantasies of salvation: Democracy, nationalism, and myth in post-communist Europe / V. Tismaneanu. - Princeton : Princeton University Press, 2009. - 256 p.

\section{REFERENCES}

1. Vaynshteyn G. Rossiya glazami Zapada: stereotipy vospriyatiya i realnosti interpretatsii [Russia as Viewed by the West: Stereotypes of Perception and Reality of Interpretation]. Neprikosnovennyy zapas, 2007, no. 1, pp. 13-23.

2. Interesy gosudarstva i prava cheloveka [The Interests of the State and Human Rights]. LevadaTsentr. Press issue of 3 April 2017. URL: https:// www.levada.ru/2017/04/03/interesy-gosudarstva-iprava-cheloveka/ (accessed 17 April 2018).

3. Ksenofobiya v 2017 godu [Xenophobia in 2017]. Levada-Tsentr. Press issue of 23 August 2017. URL: https://www.levada.ru/2017/08/23/16486/ (accessed 17 April 2018).

4. Lukasheva E.A. Sovremennaya mifologiya i realii politicheskoy i sotsialnoy zhizni [Modern Mythology and the Realia of Political and Social Life]. Trudy Instituta gosudarstva i prava Rossiyskoy akademii nauk, 2012, no. 3, pp. 5-35.

5. Malinova O.Yu. Mif kak kategoriya simvolicheskoy politiki: analiz teoreticheskikh razvilok [Myth as a Category of Symbolic Politics: Analysis of Theoretical Divergence]. Politicheskie issledovaniya, 2015, no. 4, pp. 12-21.

6. Medinskiy V.R. O russkom pyanstve, leni $i$ zhestokosti [On the Russian Alcohol Abuse, Laziness and Cruelty]. Moscow, OLMA Media Grupp, 2009. 560 p.

7. Odobrenie institutov vlasti [The Approval of Power Institutions]. Levada-Tsentr. Press issue of 25 April 2018. URL: https://www.levada.ru/2018/04/25/odobrenieinstitutov-vlasti-2/ (accessed 11 May 2018).

8. Prioritety vo vneshney politike [Foreign Policy Priorities]. Levada-Tsentr. Press issue of 17 August 2017. URL: https://www.levada.ru/2017/08/17/prioritety-vovneshnej-politike/ (accessed 17 April 2018).

9. Rossiya - velikaya derzhava [Russia is a Great Power]. VCIOM. Press issue No. 3327 of 15 March 2017. URL: https://wciom.ru/index.php?id= 236\&uid=116111 (accessed 17 April 2018).

10. Ryumin A.M. Sovremennye stereotipy o Rossii v massovom soznanii zhiteley stran Zapada: avtoref. dis.... kand. sotsiol. nauk [Modern Stereotypes about Russia in the Mass Consciousness 


\section{ПОЛИТИЧЕСКИЕ НАУКИ И РЕГИОНОВЕДЕНИЕ}

of Western People. Cand. sociol. sci. abs. diss.]. Nizhniy Novgorod, 2012. $21 \mathrm{p}$.

11. Solovey V.D. Mify o Rossii vs realnost [Myths about Russia vs Reality]. Sravnitelnaya politika, 2012, no. 1, pp. 110-116.

12. Stalinskie repressii [Stalin's Repressions]. Levada-Tsentr. Press issue of 23 May 2017. URL: https://www.levada.ru/2017/05/23/stalinskie-repressii/ (accessed 17 April 2018).

13. Surkov V. Odinochestvo polukrovki (14+) [Loneliness of the Half-Blood (14+)]. Rossiya $v$ globalnoy politike, 2018, no. 2, pp. 124-129.

14. David-Fox M. Crossing borders: modernity, ideology, and culture in Russia and the Soviet Union. Pittsburgh, University of Pittsburgh Press, 2015. 286 p.

15. Dimkann P. Russian messianism: Third Rome, revolution, communism and after. New York; London, Routledge, 2000. $235 \mathrm{p}$.

16. Foglesong D., Hahn G. M. Ten myths about Russia: Understanding and dealing with Russia's complexity and ambiguity. Problems of PostCommunism, 2002, vol. 49, no. 6, pp. 3-15.
17. Gessen M. Five myths about Russia. The Washington Post, 2016, October 7. URL: https:// www. washingtonpost.com/opinions/five-mythsabout-russia/2016/10/07/1df1671a-8bd3-11e6-bf8a3d26847eeed4_story.html?utm_term $=.3 \mathrm{~b} 4 \mathrm{~b} 69 \mathrm{f} 4 \mathrm{ee} 41$ (accessed 17 April 2018).

18. Gill G. Symbols and legitimacy in Soviet politics: The life and death of the USSR. Cambridge, Cambridge University press, 2011.364 p.

19. Malia M. Russia under Western Eyes: From the Bronze Horseman to the Lenin Mausoleum. Cambridge (Mass.); London, Harvard University Press, 1999. 514 p.

20. Shakarian P. Debunking 8 myths about Russia and the former Soviet space (October 3, 2014). Russia Direct. URL: http://www.russia-direct.org/analysis/ debunking-8-myths-about-russia-and-former-sovietspace (accessed 17 April 2018).

21. Tismaneanu V. Fantasies of salvation: Democracy, nationalism, and myth in postcommunist Europe. Princeton, Princeton university press, 2009. $256 \mathrm{p}$.

\section{Information about the Authors}

Sergey V. Biryukov, Doctor of Sciences (Politics), Professor, Researcher, Centre for Russian Studies, East China Pedagogical University, North Zhongshan Road, 3663, 200062 Shanghai, China, birs.07@mail.ru, https://orcid.org/0000-0003-4071-0464

Oleg V. Omelichkin, Doctor of Sciences (Politics), Professor of Department of World History and Sociopolitical Sciences, Kemerovo State University, Krasnaya St., 6, 650043 Kemerovo, Russian Federation, omelichkin.ov@mail.ru, https://orcid.org/0000-0001-6149-0443

\section{Информация об авторах}

Сергей Владимирович Бирюков, доктор политических наук, профессор, научный сотрудник Центра изучения России, Восточно-Китайский педагогический университет, ул. Северный Джонгшан, 3663, 200062 г. Шанхай, Китайская Народная Республика, birs.07@mail.ru, https:// orcid.org/0000-0003-4071-0464

Олег Викторович Омеличкин, доктор политических наук, профессор кафедры всеобщей истории и социально-политических наук, Кемеровский государственный университет, ул. Красная, 6, 650043 г. Кемерово, Российская Федерация, omelichkin.ov@mail.ru, https://orcid.org/00000001-6149-0443 